https://nv.nltu.edu.ua

https://doi.org/10.15421/40280616

Article received $15.06 .2018 \mathrm{p}$.

Article accepted 25.06.2018 p.

ISSN 2519-2477 (online)

УДК 66.047 .45

$@ \bowtie$ Correspondence author

A. M. Babych

andrbabi25@gmail.com

В. М. Атаманюк, М. І. Мосюк, Ю. М. Гринчук, А. М. Бабич

Національний університет "Львівська політехніка", м. Львів, Україна

\title{
ГІДРОДИНАМІКА РУХУ ТЕПЛОВОГО АГЕНТА ПІД ЧАС ФІЛЬТРАЦІЙНОГО СУШІННЯ MISCÁNTHUS GIGANTEUS
}

Наведено результати експериментальних досліджень гідродинаміки руху теплового агента крізь стаціонарний шар подрібненого miscánthus giganteus. Визначено основні параметри шару miscánthus giganteus та вибрано еквівалентний діаметр каналів між частинками $d_{e}$. Подано основні технічні характеристики miscánthus giganteus. Проведено експериментальні дослідження гідродинаміки фільтрування теплового агента крізь стаціонарний шар miscánthus giganteus. Наведено експериментальні дослідження гідродинаміки шару miscánthus giganteus від фіктивної швидкості теплового агента. Отримано рівняння, яке описує складну залежність між напором і швидкістю, зумовлену пружними властивостями miscánthus giganteus. Oтримане рівняння дає змогу прогнозувати енергетичні затрати на створення перепаду тиску під час сушіння в стаціонарному шарі miscánthus giganteus у межах зазначених похибки і меж висоти шару та фіктивної швидкості. Представлено коефіцієнт опоpy шару miscánthus giganteus у вигляді безрозмірних комплексів як функцію числа Рейнольдса. Визначено коефіцієнт гідравлічного тертя $\lambda$. Проаналізовано абсолютне значення відносної похибки між теоретично розрахованими значеннями та експериментальними даними. Одержано критеріальні залежності, які дають змогу використати отримані результати для проектування нового сушильного обладнання за подібних гідродинамічних умов.

Ключові слова: гідродинаміка; стаціонарний шар; фільтраційне сушіння; тверде біопаливо; відновлювальні джерела енергіï.

Вступ. Ситуація, яка склалась в Україні із забезпеченням іiі економіки достатніми обсягами енергоносіїв власного видобутку, гостро ставить проблему пошуку альтернативних видів палива. В умовах практично монопольної залежності від імпорту нафти й газу та значного забруднення ними довкілля Україна повинна шукати альтернативні джерела для забезпечення країни паливом й енергією, які були б екологічно чистими та не залежали від зовнішніх постачань сировини.

Одним із шляхів вирішення цього завдання є розвиток виробництва біопалива. Для збільшення обсягів використання біопалива в Україні є всі передумови, зокрема завдяки можливості вирощування швидко ростучих біоенергетичних культур, таких як miscánthus giganteus, енергетична верба, тополя та ін.

Згідно з Енергетичною стратегію України до 2035 р., Україна має намір скоротити споживання викопного палива та збільшити частку відновлюваних джерел енергії від 4 (у 2016 р.) до 25 \% (у 2035 р.) від загального обсягу постачання горючих копалин. В Україні за останні роки частка біомаси від усіх відновлюваних джерел енергії становить $64 \%$, і очікується, що ця частка залишиться основною і в майбутньому. Отже, проекти, що заміщують викопне паливо (вугілля, природний газ) біомасою, популярні в Україні зараз, і їх кількість буде збільшуватися в майбутньому (Stepanushko, 2017).

У Європі вже понад 20 років активно розвивається біоенергетика. На особливу увагу заслуговує напрям, пов'язаний із виробництвом твердих видів біопалива, зокрема пелет, за рахунок вирощування нових видів високопродуктивних багаторічних рослин, що дає змогу гарантовано отримати задану кількість біомаси необхідної якості. Однією з таких рослин є miscánthus giganteus. Площі під цю культуру щороку збільшуються, оскільки вирощування miscánthus giganteus, як сировини для виробництва біопалива, вважають одним з найменш витратних, що наведено в табл. 1 (Stepanushko, 2017).

Табл. 1. Енергетична продуктивність багаторічних біоенергетичних культур (Kindzera, Atamaniuk \& Hosovskyi, 2016)

\begin{tabular}{|c|c|c|c|c|c|}
\hline $\begin{array}{c}\text { Енергетич- } \\
\text { на культура }\end{array}$ & $\begin{array}{c}\text { Урожай } \\
\text { сирої } \\
\text { біомаси, } \\
\text { т/га }\end{array}$ & $\begin{array}{c}\text { Суха } \\
\text { речови- } \\
\text { на, \% }\end{array}$ & $\begin{array}{c}\text { Урожай } \\
\text { сухої бі- } \\
\text { омаси, } \\
\text { т/га }\end{array}$ & $\begin{array}{c}\text { Вихід } \\
\text { тердого } \\
\text { палива, } \\
\text { т/га }\end{array}$ & $\begin{array}{c}\text { Вихід } \\
\text { енергії, } \\
\text { ГкДж/га }\end{array}$ \\
\hline $\begin{array}{c}\text { Енергетич- } \\
\text { на верба }\end{array}$ & 54,6 & 50,5 & 27,3 & 32,8 & 573,3 \\
\hline $\begin{array}{c}\text { Міскантус } \\
\text { гігантський }\end{array}$ & 58,8 & 42,6 & 25,3 & 30,3 & 516,2 \\
\hline $\begin{array}{c}\text { Просо пру- } \\
\text { топодібне }\end{array}$ & 23,2 & 78,5 & 18,2 & 21,8 & 371,5 \\
\hline
\end{tabular}

Miscánthus giganteus може давати врожайність понад 25 т/га сухої речовини, але його не досить активно ви-

\section{Інформація про авторів:}

Атаманюк Володимир Михайлович, д-р техн. наук, професор, завідувач кафедри хімічної інженерії. Email: atamanyuk@ukr.net Мосюк Микола Іванович, канд. техн. наук, асистент, кафедра хімічної інженерії. Email: mosiuk@ukr.net

Гринчук Юрій Миколайович, канд. техн. наук, асистент, кафедра загальної xiмiї. Email: yura_gym@ukr.net

Бабич Андрій Миколайович, бакалавр, кафедра хімічної інженерії. Email: andrbabi25@gmail.com

Цитування за ДСту: Атаманюк В. М., Мосюк М. І., Гринчук Ю. М., Бабич А. М. Гідродинаміка руху теплового агента під час фільтраційного сушіння Miscánthus giganteus. Науковий вісник НлТУ України. 2018, т. 28, № 6. С. 84-88.

Citation APA: Atamanyuk, V. M., Mosyiuk, M. І., Grinchuk, Yu. M., \& Babych, A. M. (2018). Hydrodynamics of heat agent movement by Miscánthus giganteus filtration drying. Scientific Bulletin of UNFU, 28(6), 84-88. https://doi.org/10.15421/40280616 
користовують у нашій країні. В Україні ця рослина у великих масштабах майже не вирощується, хоча з'являються нові площі насаджень у різних регіонах. У розвитку біоенергетичної галузі відстаємо від Європи років на 5-10. Але цей інтервал щороку поступового скорочується.

Отже, можна констатувати, що на сьогодні наша держава зацікавлена в розвитку альтернативних видів енергії, зокрема біопалива, яке може замістити велику частку викопного палива.

Фізико-хімічні властивості матеріалу. Miscánthus giganteus, як сировина для виробництва твердого біопалива, має такі показники: врожайність сухої біомаси (до 25 т/га), висока теплотворна здатність (5 кВт/год/кг або 18 МДж/кг (пелети) за вологості 10 \%). Порівняно 3 іншими відновлювальними джерелами енергії, завдяки низькій природній вологості стебел (під час збирання сировини становить 15-18\%) miscánthus giganteus $є$ однією 3 найефективніших рослин для виробництва біопалива, що наведено в табл. 2 (Stepanushko, 2017).

Табл. 2. Теплотворна характеристика різних видів сировини за базової вологості (W=10 \% відповідно до міжнародного стандарту DIN-Plus) (Huzova \& Khanyk, 2000)

\begin{tabular}{|l|c|}
\hline \multicolumn{1}{|c|}{ Вид сировини } & $\begin{array}{c}\text { Теплова здатність } \\
\text { палива, МДж/кг }\end{array}$ \\
\hline Мазут & 41,0 \\
\hline Кам'яне вугілля & $27,0-30,0$ \\
\hline Буре вугілля & 27,0 \\
\hline Брикети з лузги соняшника & $21,0-21,8$ \\
\hline Брикети з деревини & $16,8-21,0$ \\
\hline Гранули з лузги соняшника & $18,5-20$ \\
\hline Брикети з соломи & $15,4-21$ \\
\hline Кора & 19,5 \\
\hline Гранули з деревини & $16,0-19,5$ \\
\hline Гранули з міскантусу & $17,0-19,0$ \\
\hline Гранули з соломи & $14,0-18,8$ \\
\hline Гранули зі стебел соняшника, кукурудзи & 17,0 \\
\hline Сухий тор & 14,7 \\
\hline Солома в тюках & 14,2 \\
\hline Солома & $10,5-12,5$ \\
\hline Дрова & $10,2-12,2$ \\
\hline Тирса дерев, опилки & $10,5-12,0$ \\
\hline Гілки плодових дерев & 10,5 \\
\hline Солома зернових культур & 10,5 \\
\hline
\end{tabular}

До позитивних якостей miscánthus giganteus також належить високий вміст целюлози у стеблах (64-71 \%), що характеризує його високу енергетичну цінність. Тонна паливних гранул 3 miscánthus giganteus еквівалентна 440 кг сирої нафти, 820 кг кам'яного вугілля, $515 \mathrm{~m}^{3}$ природного газу, 1,2 т деревини або 420 кг дизельного палива (Stepanushko, 2017).

Під час згоряння біомаси miscánthus giganteus виділяється менше вуглекислого газу, ніж було абсорбовано рослинами в процесі фотосинтезу, тому використання такого біопалива не сприяє створенню парникового ефекту, а також для його вирощування можна використовувати малородючі, піщані землі або болотисту місцевість. Таких земель в Україні налічується від 3 до 5 млн га (Stepanushko, 2017).

Технологією виробництва твердого біопалива передбачено такі стадії виробництва: подрібнення сировини, сушіння та гранулювання, пресування пелет або брикетування. Найбільш енергозатратною стадією є сушіння, що становить близько 40 \% всіх енергетичних затрат на реалізацію процесу виробництва.
На сьогодні у промисловості використовують застаріле обладнання, а саме: барабанні сушарки та сушарки киплячого шару.

Оскільки недоліком барабанної сушарки є нерівномірність перемішування висушуваного матеріалу, громіздкість конструкції та високі затрати енергоносіїв, сушарка киплячого шару має потребу в значній кількості теплової енергії для реалізації фазового переходу рідини із твердого до газоподібного агрегатного стану.

Пропонуємо використання фільтраційного сушіння, яке є най-рентабельнішим, оскільки має такі переваги: наявність механічного витіснення вільної вологи; можливість сушіння тепловим агентом 3 низьким температурним потенціалом; високі коефіцієнти тепло- й масовіддачі; невисокий гідравлічний опір; відсутність стадії очищення теплового агента після сушіння.

Гідродинаміка руху повітря крізь шар подрібненого мiscánthus giganteus значною мірою визначає кінетику фільтраційного сушіння вологого матеріалу. Існує тісний зв'язок між інтенсивністю сушіння і гідродинамікою процесу, тому що характер поля швидкостей руху струминок повітря, які омивають окремі частинки шару, визначають режим руху, який впливає на коефіцієнти тепловіддачі й масовіддачі. Окрім цього, режим руху повітря визначає товщину ламінарного пограничного шару навколо частинки, який лімітує процес як теплопередачі, так і масоперенесення вологи, що своєю чергою також визначає економічну доцільність процесу.

Рушійною силою фільтрування теплового агента крізь стаціонарний пористий шар подрібненого miscánthus giganteus $є$ перепад тиску. Тому першим етапом вивчення процесу фільтраційного сушіння є експериментальне дослідження закономірностей зміни гідравлічного опору стаціонарного шару матеріалу $(\Delta \mathrm{P})$ від фіктивної швидкості руху теплового агента $\omega$. Вiдомо, що втрати тиску в шарі дисперсного матеріалу $є$ функцією висоти шару, його гранулометричного складу, форми частинок, які утворюють шар, структурну будову шару, густину та в'язкість теплового агента.

Визначення основних параметрів шару miscánthus giganteus. Як зазначено вище, подрібнений miscánthus giganteus - це суміш частинок, що мають волокнисту форму і шорстку їх зовнішню поверхню. 3 огляду на це представити визначальний розмір стаціонарного шару одним усередненим параметром частинки неможливо. Тому, як визначальний розмір для стаціонарного шару miscánthus giganteus, крізь який фільтрується тепловий агент, було вибрано еквівалентний діаметр каналів між частинками $d_{e}$.

Основні технічні характеристики miscánthus giganteus наведено у табл. 3.

Табл. 3. Основні технічні характеристики miscánthus giganteus

\begin{tabular}{|c|c|c|c|c|}
\hline$\rho_{\text {нас. }}$ Кг $/ \mathrm{M}^{3}$ & $\rho_{\text {еф. } \mathrm{K} \Gamma / \mathrm{M}^{3}}$ & $\varepsilon_{w} \mathrm{M}^{3} / \mathrm{M}^{3}$ & $\mathrm{M}$ & $a, \mathrm{M}^{3} / \mathrm{M}^{3}$ \\
\hline 122,23 & 562 & 73,75 & 4,18 & 705 \\
\hline
\end{tabular}

Насипну густину $\rho_{\text {нас. }}$ miscánthus giganteus визначено за стандартною методикою, загальну пористість досліджуваних матеріалів $\left(\varepsilon_{u}\right)-$ пікнометричним методом. Еквівалентний діаметр каналів $\left(d_{e}\right)$, крізь які фільтрується тепловий агент, визначено із залежності

$$
d_{e}=\frac{4 \cdot \varepsilon_{u}}{a}
$$


де $a$ - питома поверхня шару miscánthus giganteus, яку визначено приладом ПМЦ - 500 .

Гідродинаміка фільтрування теплового агента крізь стаціонарний шар miscánthus giganteus (експериментальні дані). Експериментальні дослідження проводили на установці (Huzova \& Khanyk, 2000). Шар miscánthus giganteus розміщували в контейнері з перфорованою перегородкою, щоб унеможливити вплив гідравлічного опору перегородки на дослідження втрат тиску в стаціонарному шарі miscánthus giganteus, живий переріз перфорованої перегородки становив $40 \%$ (у цьому випадку опір перфорованої перегородки є значно меншим за опір шару і $є$ настільки малим, що ним можна знехтувати). У всіх експериментах використовували одну і ту саму перфоровану перегородку. Щоб виключити провалювання матеріалу за межі сушильного обладнання, діаметр отворів перфорованої перегородки повинен бути меншим, ніж розмір найменших частинок miscánthus giganteus. Експериментальні дослідження втрат тиску в шарі подрібненого miscánthus giganteus проводили для висот шару 60, 80, 100, 120, 140 мм за зміни фіктивної швидкості фільтрування теплового агента в межах $0 \leq \omega_{0} \leq 2,05 \mathrm{~m} / \mathrm{c}$.

На рис. 1 наведено експериментальні дослідження гідродинаміки шару miscánthus giganteus від фіктивної швидкості теплового агента. Як видно з графіка, криві мають параболічний характер для всіх висот шару матеріалу $(60,80,100,120,140$ мм). Це свідчить про те, що втрати тиску зумовлені як інерційною, так і в'язкісною складовими.

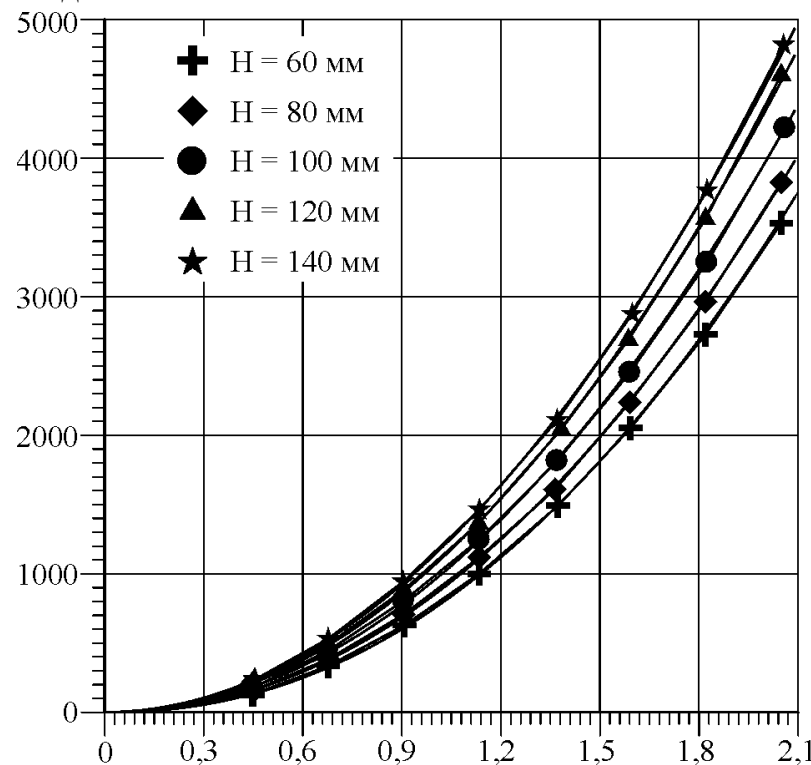

Рис. 1. Залежність втрат тиску $\Delta P$ у стаціонарному шарі Miscánthus giganteus від фіктивної швидкості $\omega_{0}$ для різних висот шару матеріалу $H$

Аналіз рис. 1 показує, що із збільшенням висоти шару гідравлічний опір зростає, однак його значення $\epsilon$ відносно невеликим, що є позитивним для організації процесу фільтраційного сушіння.

Для опису гідродинаміки руху газового потоку крізь стаціонарний пористий шар матеріалу на практиці широко використовують залежність Дарсі-Вайсбаха (Kindzera et al., 2016):

$$
\Delta P=\lambda \cdot \frac{H}{d_{e}} \cdot \frac{\rho \cdot \omega_{0}^{2}}{2 \cdot \varepsilon_{u}^{2}} .
$$

Втрати тиску $\Delta P €$ функцією швидкості $\omega_{0}$, пористості шару $\varepsilon_{u}$ i його висоти $\mathrm{H}$, які в нашому випадку $\epsilon$ змінними величинами. Для того, щоб аналітично розв'язати це рівняння, необхідно експериментально встановити зв'язок між цими величинами. Окрім цього, невідомою величиною, яку потрібно експериментально визначити, $є$ коефіцієнт опору $\lambda$. Згідно з рекомендаціями багатьох авторів, коефіцієнт опору $\lambda$ рекомендують визначати із залежності

$$
\lambda=\frac{A}{\operatorname{Re}_{e}}+B,
$$

де: $A$ і $B$ - невідомі коефіцієнти, які визначають експериментальним шляхом; $\operatorname{Re}_{e}=\omega \cdot d_{e} \cdot \rho / \mu$ - модифікований критерій Рейнольдса; $\omega=\omega_{0} / \varepsilon_{u}-$ дійсна швидкість фільтрування теплового агента в шарі матеріалу.

Відомо, що коефіцієнти $A$ і $B$ є сталими величинами для даного матеріалу. Коефіцієнт А враховує вплив в'язкісних сил, а коефіцієнт В - вплив інерційних сил на величину гідравлічного опору.

Відомо, що пористість шару матеріалу $\varepsilon_{u}$ можна визначити, коли відома його висота Н за насипної густини $\rho_{\text {нас }}$ і висота $H_{м}$, яку займає твердий матеріал за умовної густини $\rho_{e \phi}$, а також площа поперечного перерізу циліндричного контейнера $\mathrm{S}$ із залежності

$$
\varepsilon_{u}=\frac{S \cdot H-S \cdot H_{M}}{S \cdot H}=1-\frac{H_{M}}{H} .
$$

Висоту шару $H_{M}$ за ефективної (умовної) густини miscánthus giganteus $\rho_{e \phi}$ визначали із залежності

$$
H_{M}=\frac{\mathrm{G}}{\rho_{\mathrm{eq}} \cdot \mathrm{S}} .
$$

3 урахуванням залежностей (4) і (5) залежність (3) приводять до вигляду

$$
\Delta P=\left(\frac{A}{\operatorname{Re}_{e}}+B\right) \cdot \frac{H}{d_{e}} \cdot \frac{\rho \cdot \omega_{0}^{2}}{2 \cdot \varepsilon_{u}^{2}}
$$

і відповідно

$$
\frac{\Delta P}{H \cdot \omega}=A \cdot \frac{\mu \cdot a^{2}}{32 \cdot \varepsilon_{u}^{3}}+B \cdot \frac{\rho \cdot a}{8 \cdot \varepsilon_{u}^{3}} \cdot \omega_{0} .
$$

Перший доданок правої частини цього рівняння $\epsilon$ постійною величиною (для конкретних умов проведення експерименту), у другому доданку змінною величиною $є$ тільки фіктивна швидкість $\omega_{0}$. Результати перерахованої функції представлено у вигляді графічної залежності (2) для різних значень висоти, пористості та фіктивної швидкості руху теплового агента.

3 рис. 2 можна зробити висновок, що дослідні дані можна апроксимувати прямою лінією, а відрізок, що його відтинає пряма на осі ординат, дорівнює коефіцієнту $A$, а коефіцієнт $B$ визначаємо за тангенсом кута нахилу прямої до осі абсцис.

Визначивши із графічної залежності коефіцієнти $A$ i $B$, отримуємо рівняння, яке описує складну залежність між напором і швидкістю, зумовлену пружними властивостями miscánthus giganteus. Тоді рівняння (7) можна подати у такому вигляді:

$$
\frac{\Delta P}{H \cdot \omega_{0}}=585+1480 \cdot \omega_{0} .
$$

Користуючись рівнянням (8), порівняємо теоретичні й експериментальні дані. Результат порівняння представимо у вигляді графічної залежності (рис. 3). 


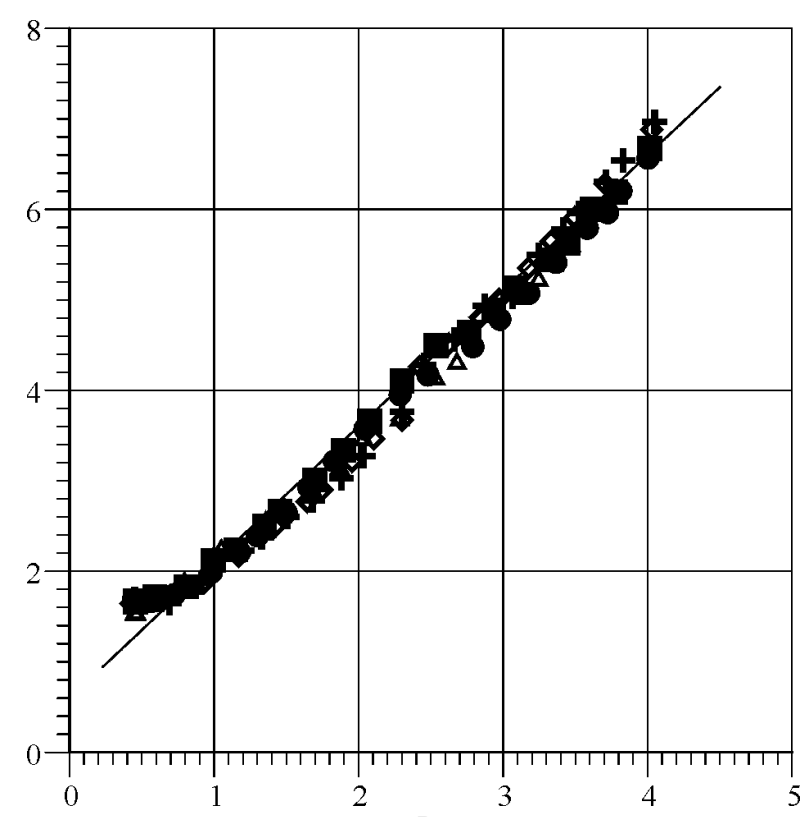

Рис. 2. Графічна залежність $\frac{\Delta P}{H \cdot \omega_{0}}=f\left(\omega_{0}\right)$ для визначення невідомих коефіцієнтів $A$ і $B$

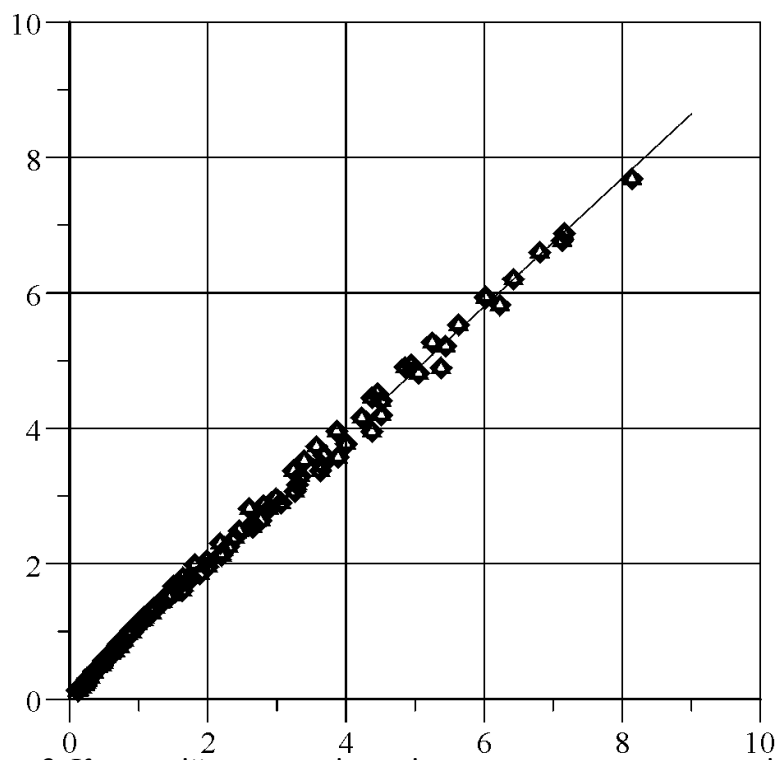

Рис. 3. Кореляційна залежність між розрахованими на основі рівнянь (8) даними та експериментальними значеннями

Максимальна похибка між теоретичними й експериментальними значеннями не перевищує $13 \%$.

Отримане рівняння (8) дає змогу прогнозувати енергетичні затрати на створення перепаду тиску під час сушіння у стаціонарному шарі miscánthus giganteus у межах вказаної похибки і вказаних вище меж висоти шару та фіктивної швидкості. Однак у цьому випадку коефіцієнт гідравлічного тертя виражений у неявній формі. Ця залежність $€$ справедливою лише для того обладнання, на якому проводилися експерименти й лише для вказаних умов експерименту.

Для того, щоб результати експериментальних досліджень можна було поширити для проектних розрахунків промислових установок фільтраційного сушіння, їх необхідно узагальнювати на основі безрозмірних комплексів, або визначити коефіцієнт гідравлічного тертя в явній формі як функцію від числа Рейнольдса. Це дасть змогу використовувати залежність (3) у випадку переналагодження обладнання на більшу або меншу продуктивність залежно від потреб виробництва.
Коефіцієнт опору шару miscánthus giganteus можна визначити із залежності (3) із врахуванням залежності (4), представивши його у вигляді безрозмірних комплексів як функцію числа Рейнольдса

$$
\frac{\Delta P \cdot \varepsilon_{u}^{2} \cdot d_{e}}{\rho \cdot \omega_{0}^{2} \cdot H}=\frac{E u \cdot d_{e}}{H}=\frac{\lambda}{2}=f(\mathrm{Re}),
$$$$
\text { звідки } \quad \lambda=2 \cdot \frac{E u \cdot d_{e}}{H}=f(\mathrm{Re}) \text {. }
$$

Для визначення коефіцієнта опору $\lambda$ представимо експериментальні дані, наведені на рис. 1 , у вигляді функціональної залежності $\lambda=f(\operatorname{Re})-$ на рис. 4 .

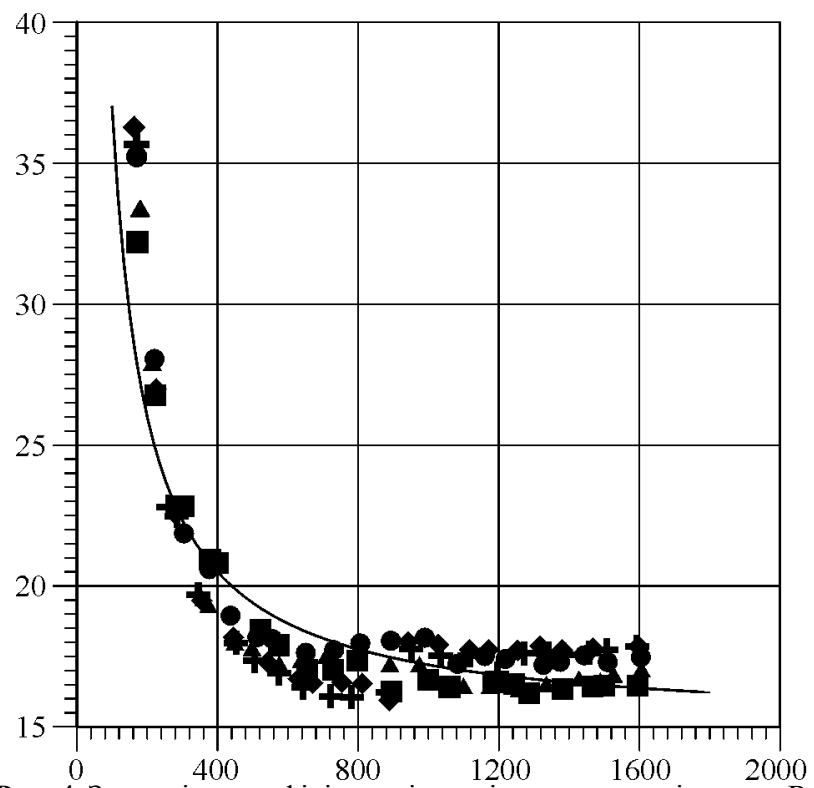

Рис. 4. Залежність коефіцієнта гідравлічного опору від числа $\mathrm{Re}_{\mathrm{e}}$

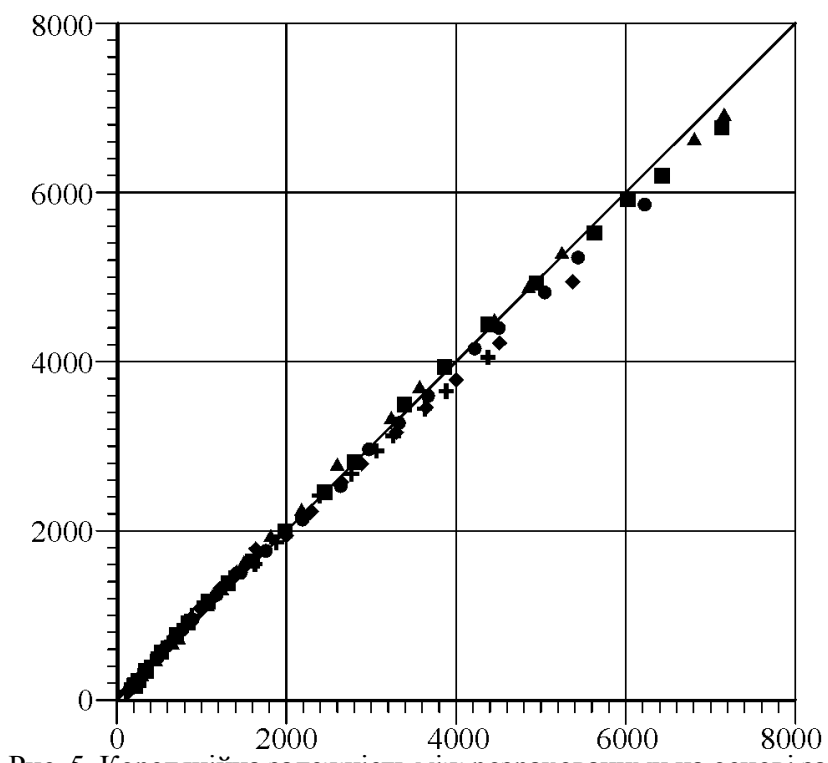

Рис. 5. Кореляційна залежність між розрахованими на основі залежності (3) з урахуванням (11) та експериментальними даними

Апроксимація експериментальних результатів степеневою функцією (див. рис. 4) дає змогу представити коефіцієнт гідравлічного опору в такому вигляді (Matkivska, Loza \& Hnativ, 2016):

$$
\lambda=\frac{1800}{\operatorname{Re}_{e}}+17 .
$$

Безрозмірна форма представлення експериментальних результатів дає змогу, користуючись теорією подібності, застосовувати отриману залежність (11) для прогнозування енергетичних затрат на процес сушіння під 
час проектування пілотних або промислових сушильних установок і на етапі проектування встановлювати економічну доцільність модернізації виробництва (Atamaniuk, Huzova \& Patrii, 2016; Kindzera, Atamaniuk \& Hosovskyi, 2016). Визначений коефіцієнт гідравлічного тертя $\lambda$ дає змогу прогнозувати енергетичні затрати на процес фільтраційного сушіння в широких межах швидкості фільтрування теплового агента $(170 \leq \operatorname{Re} \leq 1600)$.

Аналіз рис. 5 показує, що абсолютне значення відносної похибки між теоретично розрахованими значеннями за залежністю (3) із врахуванням (11) й експериментальними даними, наведеними на рис. 3 , не перевищує $13 \%$. Це означає, що ці залежності можна рекомендувати для використання їх на практиці для прогнозування енергетичних затрат на створення перепаду тиску під час розрахунку й проектування установок фільтраційного сушіння miscánthus giganteus.

\section{Перелік використаних джерел}

Atamaniuk, V. M., Huzova, I. O., \& Patrii, N. I. (2016). Hidrodynamika sushinnia kavovoho shlamu. Khimichna promyslovist Ukrainy, 2, 12-17. [In Ukrainian].
Humentyk, M. (2017). Osoblyvosti vyroshchuvannia enerhetychnykh kultur ta vyrobnytstva biopalyva. Retrieved from: http://saee.gov.ua/sites/default/files/Osoblyvosti vyroshhuvannya energetychnyx kultur ta vyrobnycztva biopalyva.pdf. [In Ukrainian].

Huzova, I. O., \& Khanyk, Ya. M. (2000). Hidrodynamika filtratsiinoho sushinnia dyspersnykh materialiv. Visnyk $D U$ "Lvivska politekhnika": Khimiia, tekhnolohiia rechovyn ta yikh zastosuvannia, 414, 168-172. [In Ukrainian].

Kindzera, D. P., Atamaniuk, V. M., \& Hosovskyi, P. P. (2016). Kinetyka filtratsiinoho sushinnia podribnenykh stebel soniashnyka. Naukovi pratsi onakht, 80(1), 32-38. [In Ukrainian].

Kindzera, D. P., Pelekh, M. P., Hosovskyi, R. R., \& Kindzera, A. R. (2016). Zmenshennia enerhozatrat protsesu vyrobnytstva tverdoho biopalyva ta pidvyshchennia yakisnykh pokaznykiv produktsii. Visnyk Natsionalnoho universytetu "Lvivska politekhnika": Seriia "Khimiia, tekhnolohiia rechovyn ta yikh zastosuvannia", 841, 302308. [In Ukrainian].

Matkivska, I. Ya., Loza, R. Z., \& Hnativ, Z. Ya. (2016). Hidrodynamika filtruvannia teplovoho ahentu kriz statsionarnyi shar buriakovoho zhomu. Visnyk Natsionalnoho universytetu "Lvivska politekhnika": Seriia "Khimiia, tekhnolohiia rechovyn ta yikh zastosuvannia", 841, 321-325. [In Ukrainian].

Stepanushko, L. (2017). Miskantus hihantskyi : hariacha propozytsiia. Retrieved from: http://www.propozitsiya.com/ua/miskantusgigantskiy-goryachee-predlozhenie. [In Ukrainian].

В. М. Атаманюк, Н. И. Мосюк, Ю. Н. Гринчук, А. Н. Бабич Национальный университет "Львовская политехника", г. Львов, Украина

Приведены результаты экспериментальных исследований гидродинамики движения теплового агента через стационарный слой измельченного miscánthus giganteus. Определены основные параметры слоя miscánthus giganteus и выбран эквивалентный диаметр каналов между частицами. Представлены основные технические характеристики miscánthus giganteus. Проведены экспериментальные исследования гидродинамики фильтрации теплового агента через стационарный слой miscánthus giganteus. Приведены экспериментальные исследования гидродинамики слоя miscánthus giganteus от фиктивной скорости теплового агента. Получено уравнение, описывающее сложную зависимость между напором и скоростью, вызванную упругими свойствами miscánthus giganteus. Полученное уравнение позволяет прогнозировать энергетические затраты на создание перепада давления во время сушки в стационарном слое miscánthus giganteus в пределах указанной погрешности и вышеуказанных границ высоты слоя и фиктивной скорости. Представлен коэффициент сопротивления слоя miscánthus giganteus в виде безразмерных комплексов как функция числа Рейнольдса. Определен коэффициент гидравлического трения. Проанализирован абсолютное значение относительной погрешности между теоретически рассчитанными значениями и экспериментальными данными. Получены критериальные зависимости, позволяющие использовать полученные результаты для проектирования нового сушильного оборудования в подобных гидродинамических условиях.

Ключевые слова: гидродинамика; стационарный слой; фильтрационная сушка; твердое биотопливо; возобновляемые источники энергии.

V. M. Atamanyuk, M. I. Mosyiuk, Yu. M. Grinchuk, A. M. Babych Lviv Polytechnic National University, Lviv, Ukraine

\section{HYDRODYNAMICS OF HEAT AGENT MOVEMENT BY MISCÁNTHUS GIGANTEUS FILTRATION DRYING}

Experimental studies of pressure losses in a layer of crushed miscánthus giganteus for changes in the fake rate of filtration of the thermal agent and also hydrodynamics of the layer miscanthus giganteus from the fictitious rate of the thermal agent, which are parabolic in nature for all the heights of the material layer, are presented. The hydrodynamics of the flow of gas through a stationary porous layer of material using Darcy - Weissbach dependence is described. The porosity of the material layer is determined. The equation describing the complex dependence between the pressure and the speed caused by the elastic properties of miscánthus giganteus is obtained. The results of these functions are derived for different values of height, porosity and false speed. An equation describing the complex dependence between the pressure and the speed caused by the elastic properties of miscánthus giganteus is obtained. Comparative theoretical and experimental data are presented. The obtained equation allows predicting the energy costs of creating a pressure drop during drying in the stationary layer miscánthus giganteus within the limits of the height of the layer and fictitious velocity. The relationship between pressure flow, speed, porosity, and altitude is experimentally defined. The coefficient of resistance of the miscánthus giantheus layer is determined and presented in the form of dimensionless complexes as a function of the Reynolds number. Experimental data for determining the resistance coefficient is provided. Experimental results are presented that allow predicting energy costs for the drying process. The hydraulic friction coefficient is determined which enables to predict the energy costs of the filtration drying process in the wide limits of the filtration rate of the thermal agent. The absolute value of the relative error between the theoretical calculation and experimental data is analyzed. We recommend dependencies that can be used in practice to predict the energy costs of creating a pressure drop during the calculation and design of miscánthus giganteus filtration drying installations.

Keywords: hydrodynamics; stationary layer; filtration drying; solid biofuels; renewable energy sources. 